\title{
STAND LEVEL CO, FLUX EXAMINATION OF WEED SPECIES WITH DIFFERENT ORIGIN AND FUNCTIONAL GROUPS
}

\author{
NÉMETH, Z. ${ }^{*}$ - SKUTAI, J. ${ }^{2}$ - PÓSA, P. ${ }^{1}$-SZIRMAI, O. ${ }^{2}$ - CZÓBEL, SZ. ${ }^{1}$ \\ ${ }^{I}$ Department of Nature Conservation and Landscape Ecology, Szent István University, Páter \\ Károly street 1., Gödöllö, H-2100, Hungary \\ ${ }^{2}$ Botanical Garden, Szent István University, Páter Károly street 1., Gödöllö, H-2100, Hungary \\ *Corresponding author \\ e-mail: nemeth.zoltan@capriovus.eu; phone: +36-20-571-0913 \\ (Received $13^{\text {th }}$ Mar 2017; accepted $2^{\text {nd }}$ Jun 2017)
}

\begin{abstract}
Although the ecological attributes of many weed species are well-known, their ecophysiological relations - particularly at stand level - are scarcely researched. Based on this the main objectives of our examination are to measure the stand level $\mathrm{CO}_{2}$ flux (NEE) for 5 weed species generally widespread in Central Europe as well as to explore the dependence of NEE on air temperature, radiation and stand level evapotranspiration. The selected weed species represent archaeophyte and neophyte plants as well as different functional groups $\left(\mathrm{C}_{3}, \mathrm{C}_{4}\right.$, therophytes and cryptophytes). The research covering an entire vegetation cycle of the weed species has been implemented ex situ in 15 patches of the Szent István University's Botanical Garden. Stands of the involved species showed really significant $\mathrm{CO}_{2}$ uptake for months. This value is the multiple of what is indicated in literature regarding Central European herbaceous vegetation (e.g. grasslands) - this fact can be one of the key factors leading to the success of this plant group. By comparing the average $\mathrm{CO}_{2}$ fluxes of these five weed species in the entire vegetation period it can be concluded that the values of the two endemic species are almost completely identical exceeding the average values of non-endemic $\mathrm{C}_{4}$ weed species. Furthermore, significant linear regression $(\mathrm{P}<0.05)$ has been observed between the net ecosystem $\mathrm{CO}_{2}$ gas exchange of Ambrosia artemisiifolia and Chenopodium album and the values of stand level evapotranspiration.
\end{abstract}

Keywords: canopy chambers; weeds; net ecosystem; carbondioxide exchange; dependence

Abbrevations: Ama ret-Amaranthus retroflexus; Amb art-Ambrosia artemisiifolia; Art vul-Artemisia vulgaris; Che alb - Chenopodium album; ET - evapotranspiration; LAI - leaf area index; NEE - net ecosystem $\mathrm{CO}_{2}$ exchange; PPFD - photosynthetically active photon flux density; Sor hal - Sorghum halepense; $\mathrm{T}_{\text {air }}-$ air temperature

\section{Introduction}

One of the main objectives of recent international ecosystem researches is to measure the cycles of important greenhouse gases (including carbon dioxide) in different habitats (e.g. Yamuki et al., 1997; MacDonald et al., 1998; Dong et al., 2000; Papen et al., 2001; Hefting et al., 2003; Horváth et al., 2006). Such European projects have examined ecosystems of grasslands, shrubs, waters, watersides and forests together with their plant communities/stands. However it is surprising that stand level research regarding greenhouse gas fluxes of weed stands has not yet been conducted although they can have fundamental influence on the carbon balance of certain areas due to their wide range and constant expansion. Ecological characteristics of several weed species are well-explored (e.g. Holzner and Numata, 2013; Čekić and Kovačević, 2015; Kleunen et al., 2015) but their stand level ecophysiological relations are hardly examined.

Examinations implemented so far on greenhouse gases in relation with weeds mainly focused on the impacts of increased $\mathrm{CO}_{2}$ concentration on the growth and production of 
weed species instead of their $\mathrm{CO}_{2}$ fluxes. Based on the responses given by different $\mathrm{C}_{3}$ and $\mathrm{C}_{4}$ weed species on increased $\mathrm{CO}_{2}$ concentration in the air the highest growth rate among the involved taxa belonged to the $\mathrm{C}_{4}$ Amaranthus retroflexus. In case of Ambrosia growth was more intensive under increased $\mathrm{CO}_{2}$ concentration in the first half of the examination period while in the second half current atmospheric conditions (i.e. $350 \mathrm{ppm}$ ) resulted higher growth (Garbutt et al., 1990). The amount of reproductive biomass was increased in case of Amaranthus retroflexus, Chenopodium album and Ambrosia artemisiifolia when atmospheric $\mathrm{CO}_{2}$ concentration was higher. Strong correlation can be observed between the change of leaf surface and accumulation of biomass in case of Abutilon theophrasti and Amaranthus retroflexus (Akerly et al., 1992). Development of leaves has been accelerated for these species by increasing either the air temperature or the $\mathrm{CO}_{2}$ concentration.

Other researchers examined the impacts of not only increased but also decreased carbon dioxide concentration on - among others $-\mathrm{C}_{3}$ and $\mathrm{C}_{4}$ weed species (Dipperey et al., 1994.). Regarding $\mathrm{C}_{4}$ taxa $\mathrm{CO}_{2}$ concentration had no effect on either growth rate or total biomass within the first 35 days following germination. In case of $\mathrm{C}_{3}$ taxa biomass showed positive correlation with higher atmospheric $\mathrm{CO}_{2}$ concentration.

The effect of aridity was different in the involved functional groups (Ward et al., 1999). Photosynthetic rate of plants with good availability rate has increased when atmospheric $\mathrm{CO}_{2}$ concentration was higher but their leaf surface and biomass has not changed. As opposed to that both leaf level $\mathrm{CO}_{2}$ uptake and biomass of $\mathrm{C}_{3}$ taxa increased under the concentration of $700 \mathrm{ppm}$. Due to the aridity leaf surface of $\mathrm{C}_{3}$ plants reduced significantly; as a consequence of that water potential value of remaining leaves became relatively high. The LAI of $\mathrm{C}_{4}$ plants decreased in smaller extent. Lower water potential value was measured in their leaves. Under non-limiting nutrient provision whole individuals of $\mathrm{C}_{3}$ taxa developed significantly as a result of increased $\mathrm{CO}_{2}$ concentration while more moderate growth has been examined in case of $\mathrm{C}_{4}$ plants (Bernacchi et al., 2000). In limiting environment neither types showed significant development. Shoot-root rate remained unchained or decreased in the observed taxa as a result of higher $\mathrm{CO}_{2}$ concentration.

Considerable competition can occur among weeds in mixed communities as a result of which the amount of biomass - both above and below soil surface - change as well as the habit of the plants (e.g. Bazzaz et al., 1989). Interference of different species can be observed not only in competition for resources. For instance, Artemisia vulgaris has allelopathic characteristics among the examined weed species (Barney et al., 2005). In mixed vegetation species can influence not only negatively the development of other taxa. Weeds growing under higher plants can utilise absorbed and photosynthetically active radiation with higher efficiency (Gramig et al., 2006). Selected parameters can be examined in a taxon specific way (Borjigidai et al., 2008) in monodominant stands of the selected weed species.

By examining archaeophyte and neophyte weed species representing different physiognomy and functional groups the $\mathrm{CO}_{2}$ balance of these stands and plant communities can be explored. Photosynthetic capacity of invasive plants is usually higher (Nielsen et al., 1993; Patterson et al., 1998) but their mass invasion is not a primary consequence of this feature (Brodersen et al., 2008).

Measurement of carbon dioxide fluxes in the weed stands can also provide a basis in the future for monitoring alterations occurring as a result of global climate change regarding these stands and plant communities dominated by these species. Due to 
climate change extreme weather conditions become more frequent (Brodersen et al., 2008) to which taxa give different answers. Examining the success of adaptation to extreme precipitation conditions may help when establishing a prognosis in relation to the future range of certain weed species since different types of photosynthesis influence the water utilisation efficiency of plants (Niu et al., 2005; Sharkawy, 2009).

The main objective of our research is to implement comparative measurement of carbon dioxide fluxes at stand level in case of five weed species generally widespread in Central Europe (Lososová et al., 2006): Amaranthus retroflexus, Ambrosia artemisiifolia, Artemisia vulgaris, Chenopodium album and Sorghum halepense. Dependence of NEE on air temperature, radiation and stand level evapotranspiration has also been examined.

When selecting the species it has been taken into consideration that archaeophyte (Artemisia vulgaris, Chenopodium album) and neophyte (Amaranthus retroflexus, Ambrosia artemisiifolia, Sorghum halepense) plants as well as members of different functional groups $/ \mathrm{C}_{3}$ (Ambrosia artemisiifolia, Artemisia vulgaris, Chenopodium album), $\mathrm{C}_{4}$ (Amaranthus retroflexus, Sorghum halepense); therophyte (Amaranthus retroflexus, Ambrosia artemisiifolia, Artemisia vulgaris, Chenopodium album), cryptophyte (Sorghum halepense)/ species and angiosperms (3 families and 5 genera) are all to be represented.

\section{Materials and Methods}

\section{Site description}

Examination covering the entire vegetation cycle of weed species have been implemented in the Experimental Site of Szent István Egyetem Botanical Garden (Gödöllö $19^{\circ} 14^{\prime} \mathrm{E}, 4^{\circ} 25^{\prime} \mathrm{N}, 250 \mathrm{~m}$ elevation) (Szirmai et al., 2014). Mean annual temperature is $10.5^{\circ} \mathrm{C}$; average amount of precipitation is $500 \mathrm{~mm}$. The soil of the site is loose and moderately calcareous sand (Szente et al., 1993b). 15 homogenous stand patches have been created within the selected area. The size of the patches was 1 by 1 metre, with 3 repetitions by species and by examinations. Proper isolation distances have been kept among the stands. Parcels were established following random block pattern in order to avoid spot effect.

\section{Stand level measurements}

Measurements were conducted in the 2008 vegetation period by using CIRAS-2 infrared gas analyser (PP Systems, Hitchin, UK) and the so-called "open chamber" method. Measurements have been taken weekly or in every two weeks with the help of transparent, water-clear plexi chambers adjusted to the actual height of stands. The chamber used initially consisted of a cylinder wall with $60 \mathrm{~cm}$ diameter and a halfsphere shaped transparent part installed at the top airtight (in details see Czóbel et al., 2004). In order to harmonise the tools with the actual height of stands $70 \mathrm{~cm}$ and 200 $\mathrm{cm}$ high chambers were used. External fans ensured the consistent mixing of air within the chambers as well as air exchange. The same measurement technique has been applied regardless the size of the chambers. Measurements were taken between $11 \mathrm{am}$ and $3 \mathrm{pm}$ under cloudless and clean sky. Data recording took at least 30 minutes for each weed species and treatment. The equipment measured the difference in stand level $\mathrm{CO}_{2}$ flux (in the incoming and outgoing tubes of the chamber) by taking 10 samples per 
minute. It also recorded the photosynthetically active radiation (PPFD), air temperature $\left(\mathrm{T}_{\text {air }}\right)$ and evapotranspiration (ET) in the stand covered by chamber. Average temperatures of the given stand have been used for $\mathrm{CO}_{2}$ flux calculations. The following differential equation has been applied when calculating $\mathrm{CO}_{2}$ flux:

$$
\mathrm{F}=\Delta \mathrm{c} * \mathrm{Q} / \mathrm{A}
$$

where ' $\mathrm{F}$ ' is the stand level flux $/ \mathrm{CO}_{2}$ uptake of the plant stand, vegetation and soil respiration in case of $\mathrm{CO}_{2}$ flux; the resultant of the evaporation regarding soil surface covered by vegetation in case of evapotranspiration/ $\left(\mathrm{mol} \mathrm{m} \mathrm{m}^{-2} \mathrm{~s}^{-1}\right)$, ' $\Delta \mathrm{c}$ ' represents the difference in incoming and outgoing concentration $/ \mathrm{CO}_{2}$ or $\mathrm{H}_{2} \mathrm{O} /\left(\mathrm{mol} \mathrm{m}{ }^{-3}\right)$, 'Q' stands for flowrate $\left(\mathrm{m}^{-3} \mathrm{~s}^{-1}\right)$ and ' $\mathrm{A}$ ' is the soil surface covered by the chamber $\left(\mathrm{m}^{2}\right)$.

Following quality control raw data have been manually filtered where negative evapotranspiration values as well as outliers recorded at the initiating and final phases of the measurement (due to human respiration) have not been taken into account.

Parallel to $\mathrm{CO}_{2}$ flux measurements ET, PPFD and $\mathrm{T}_{\text {air }}$ have been recorded by patches with a portable infrared gas analyser /CIRAS-2 (PP Systems, Hitchin, UK)/

\section{Statistics}

Only significant correlations have been represented in the figures indicating the strength of the correlation. The strongest significant correlation has been fitted to the data in all cases. Values of regression have been calculated by SigmaPlot 8.0 software. In case of time series t-tests were implemented to check the level of significance regarding correlation values, impacts of manipulation experiments and the differences among the involved taxa. Standard deviance (SD) values are indicated in the figures.

Figures have been created by using SigmaPlot 8.0 software.

\section{Results and Discussion}

\section{Net ecosystem $\mathrm{CO}_{2}$ exchange (NEE) examinations}

All five species reached considerable $\mathrm{CO}_{2}$ exchange values until the time of cutting (Fig. 1). Significant values of standard deviance is connected to high $\mathrm{CO}_{2}$ fluxes regardless of the species. Stands of Ambrosia artemisiifolia and Sorghum halepense reached the maximum of $\mathrm{CO}_{2}$ uptake relatively late. Maximal value of $\mathrm{CO}_{2}$ fixation, in case of both species, can be the multiple compared to that of either a fully developed loess grassland (Frank et al., 2002; Hunt et al., 2002; Czóbel, 2007; Czóbel et al., 2008) or a stand of spring forest geophytes (BARCZA et al. 2011). Different functional groups cannot be significantly separate based on their NEE values. During spring both early germinating $\mathrm{C}_{3}$ species (Che alb: -9.20; Art vulg: -6.28) produced remarkably high NEE values even from May while stands of $\mathrm{C}_{4}$ weeds showed lower $\mathrm{CO}_{2}$ uptake (Ama ret: 4.06; Sor hal: -2.53) in this period. Average net ecosystem exchange increased in a great extent (Ama ret: -8.29; Sor hal: -8.44) during summer. Stands of Amb art reached the highest value of the summer period $(-15.95)$ by showing great increase in biomass and NEE. In this season average NEE value of Art vul also increased (-9.98) while in stands of white goosefoot it has been reduced (-7.66). Order of $\mathrm{CO}_{2}$ fixation among the species has not reflected the amount of biomass. Following cutting $\mathrm{CO}_{2}$ exchange of the weed species significantly decreased as a result of both losing the majority of foliage 
and the poor regeneration due to aridity stress, therefore differences among taxa have been levelled off. During the autumn period Ambrosia artemisiifolia and Sorghum halepense showed the highest (-2.85) and the lowest (-0.85) average NEE value, respectively.

In case of Amaranthus retroflexus until uptake irrigated stand and no-precipitation stand showed the most intensive and lowest $\mathrm{CO}_{2}$ uptake, respectively.

NEE averages of the examined weeds remarkably exceeded values measured in temperate grasslands (e.g. Frank et al., 2002; Hunt et al., 2002; Soussana et al., 2007). Compared to grasslands the examined weed species were characterised by high $\mathrm{CO}_{2}$ fixation even in the arid summer period (Valentini et al., 1995; Suyker et al., 2003; Li et al., 2005; Pintér et al., 2008).

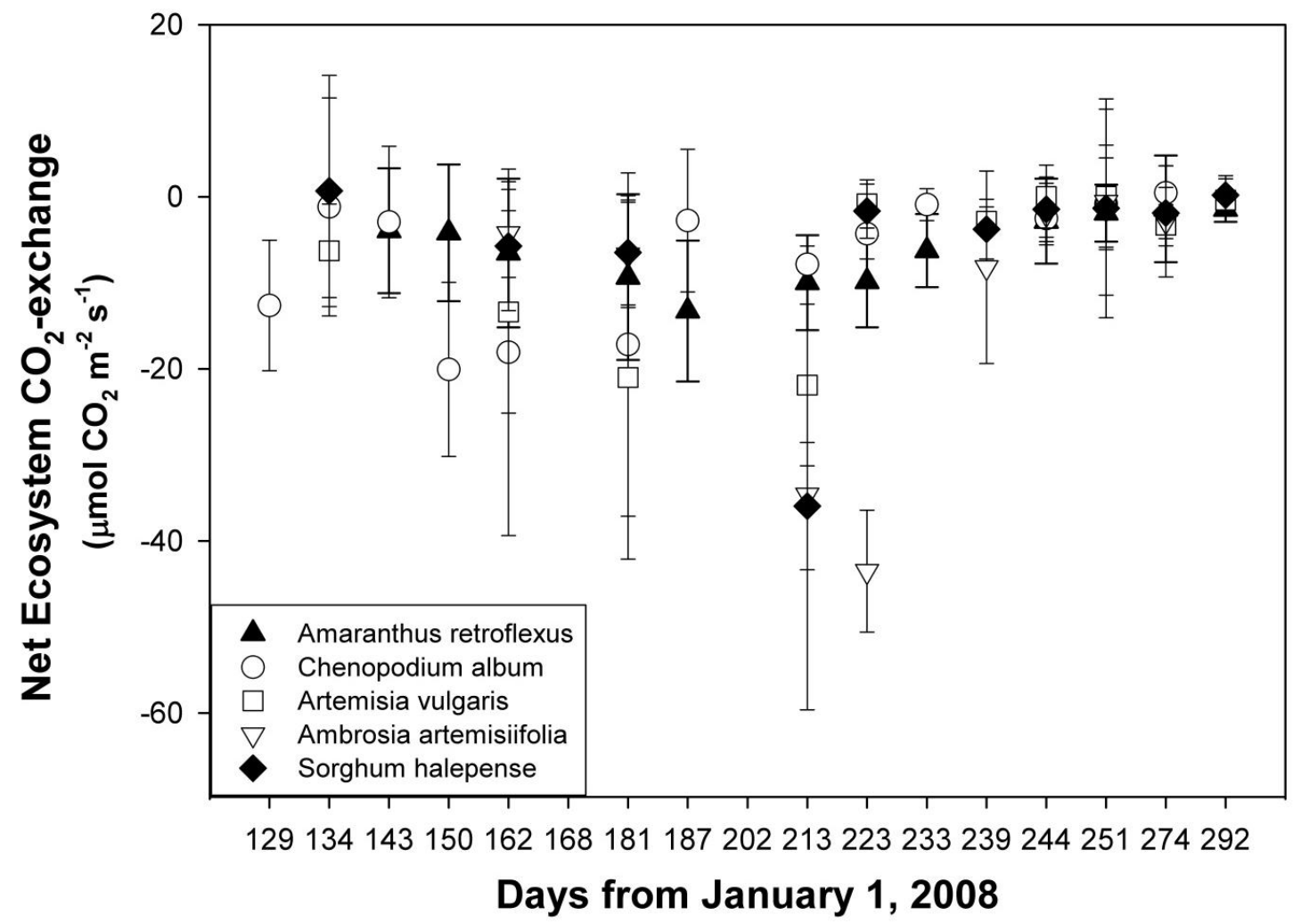

Figure 1. Seasonal dynamics of net ecosystem $\mathrm{CO}_{2}$ exchange (NEE) regarding the examined weed species during an entire vegetation period

\section{Dependence of NEE on light, temperature and evapotranspiration}

As regards of NEE light dependence no significant difference could be observed among neither the 5 examined weed species nor $\mathrm{C}_{3}$ and $\mathrm{C}_{4}$ taxa (Fig. 2). Positive correlation was found between $\mathrm{CO}_{2}$ uptake value of the stands and PPFD. In stands of Chenopodium album this relation was significant when using exponential fit $(\mathrm{P}<0.05)$. The most intensive $\mathrm{CO}_{2}$ fixation was measured when PPFD value ranged between 1400 and 1600.

$\mathrm{CO}_{2}$ fixation of the stands showed Gaussian curve when their dependence on air temperature has been examined (Fig. 3). No clear difference could be observed between $\mathrm{C}_{4}$ and $\mathrm{C}_{3}$ species. Correlation between the two parameters was significant in stands of Chenopodium album $(\mathrm{P}<0.05)$. 


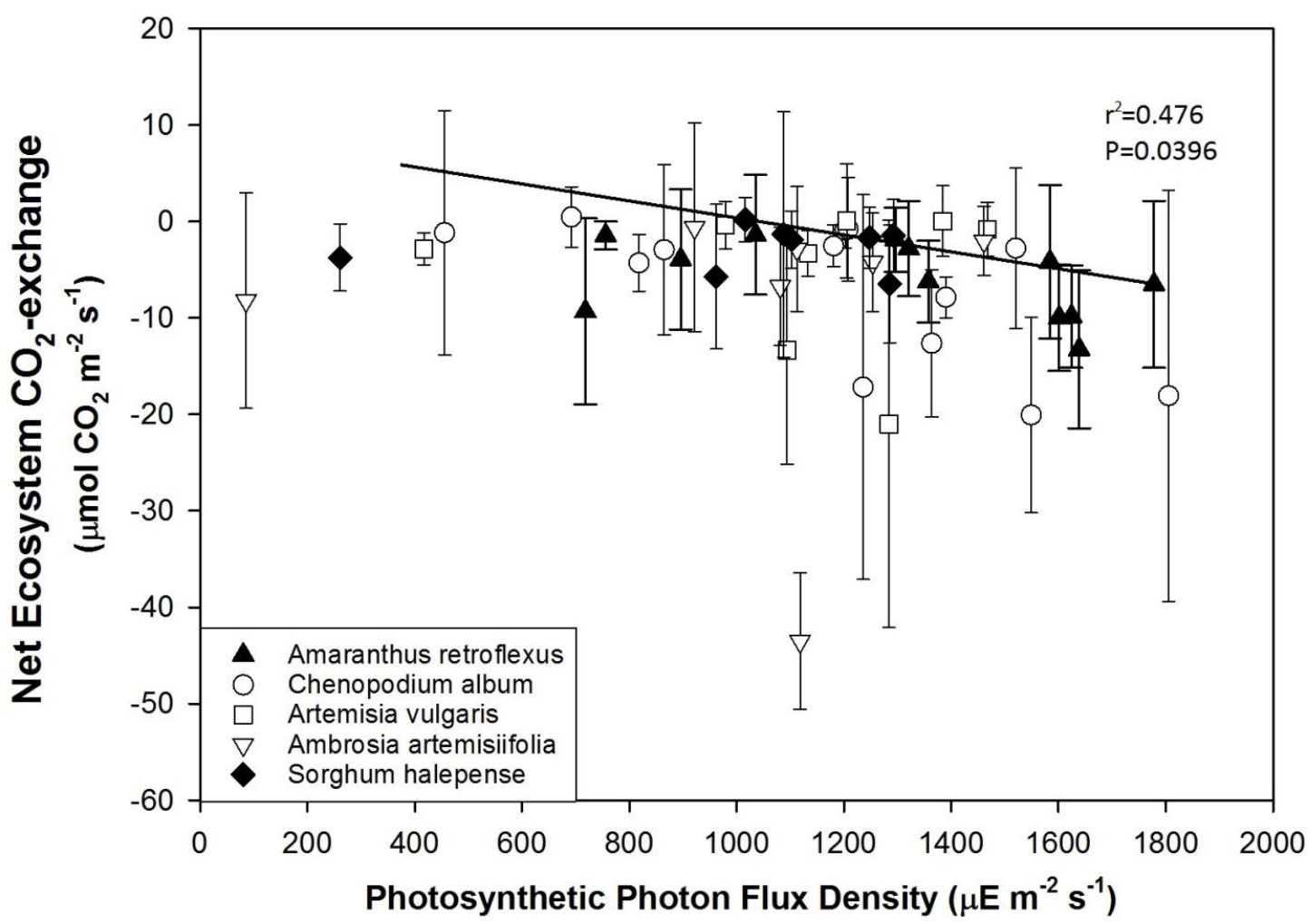

Figure 2. Dependence of net ecosystem $\mathrm{CO}_{2}$ exchange (NEE) regarding the examined weed species on photosynthetically active radiation (PPFD)

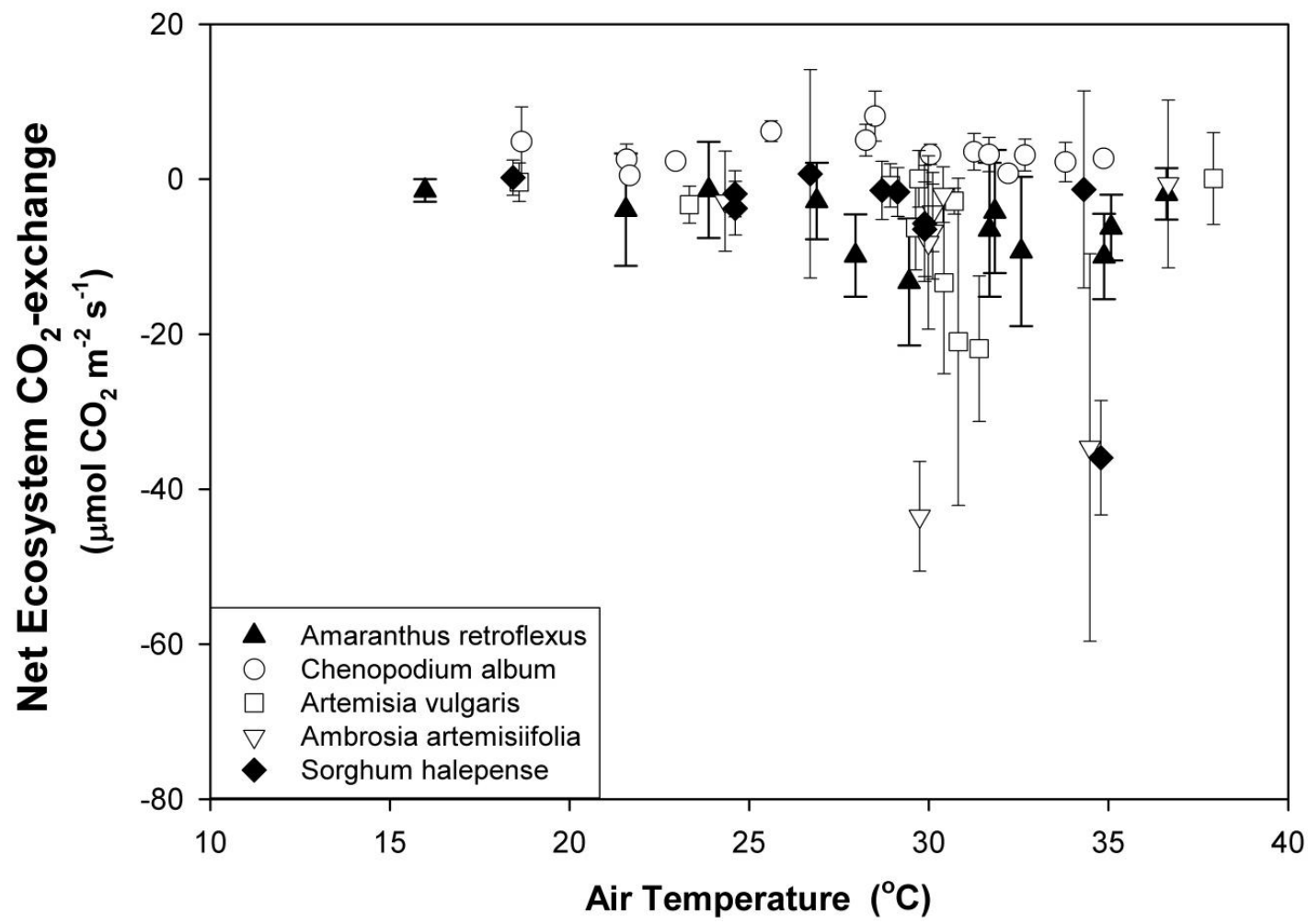

Figure 3. Dependence of net ecosystem $\mathrm{CO}_{2}$ exchange (NEE) regarding the examined weed species on air temperature $\left(T_{\text {air }}\right)$ 
Considering $\mathrm{CO}_{2}$ fixation optimum heat ranged between 28 and $35{ }^{\circ} \mathrm{C}$ for all five species. Gas exchange intensity continuously increased up to $30{ }^{\circ} \mathrm{C}$ in case of each taxon while considerable retrogression was observed over $35^{\circ} \mathrm{C}$. Latter phenomenon was experienced for $\mathrm{C}_{4}$ type weeds also, thus presumably not only stomatal closure $\left(\mathrm{C}_{3}\right)$ but also lover level of soil humidity contributed in its development.

Positive correlation could be noticed between $\mathrm{CO}_{2}$ uptake and ET within the examined stands (Fig. 4). ET dependence of NEE did not show significant distinction regarding the plant species and functional groups. However, significant linear regression $(\mathrm{P}<0.05)$ could be observed between net ecosystem $\mathrm{CO}_{2}$ exchange and stand level evapotranspiration in case of Ambrosia artemisiifolia and Chenopodium album. When conducting the measures increased ET was usually coupled with slightly higher $\mathrm{CO}_{2}$ uptake.

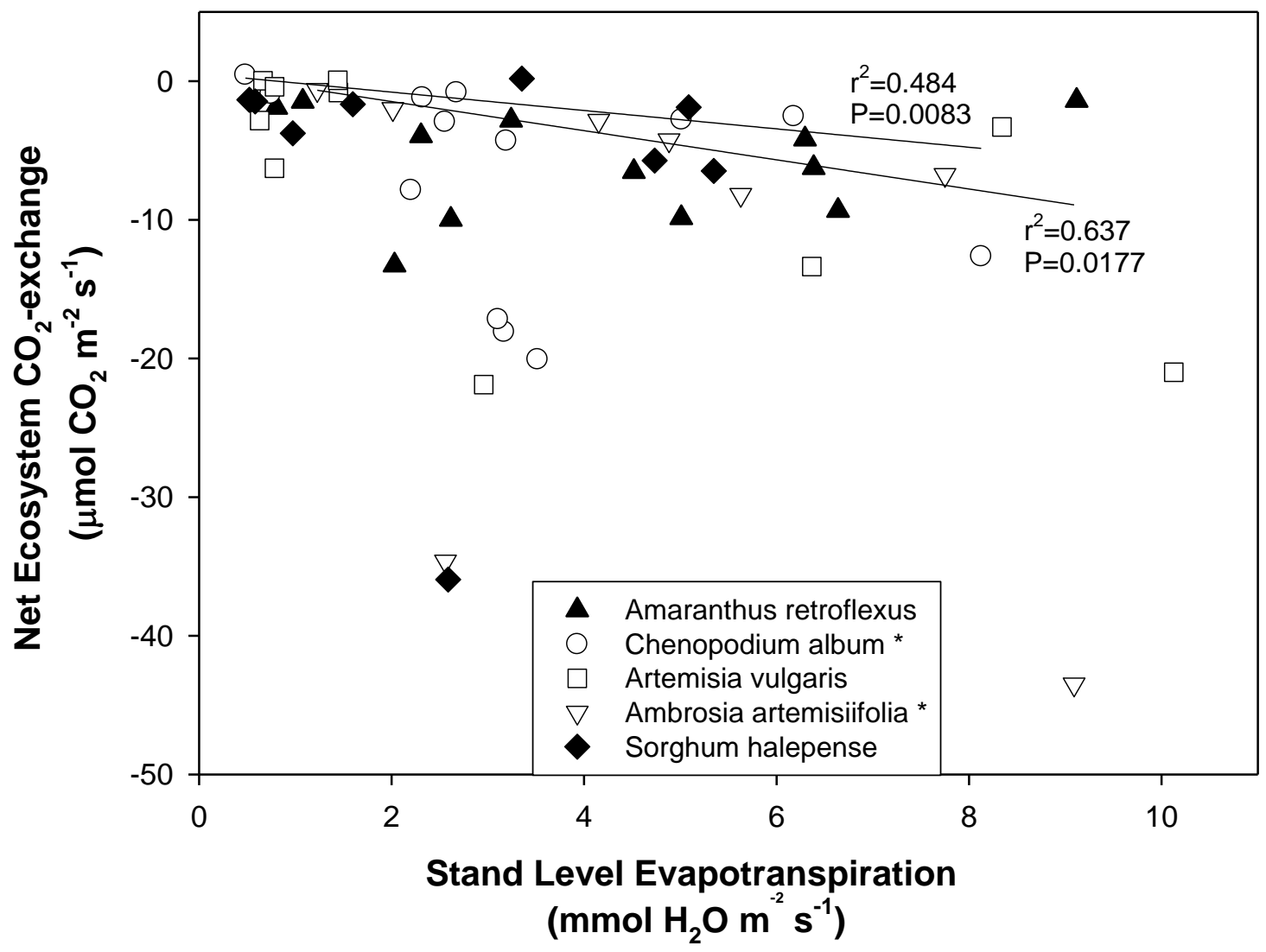

Figure 4. Dependence of net ecosystem $\mathrm{CO}_{2}$ exchange (NEE) regarding the examined weed species on evapotranspiration (ET)

\section{Conclusions}

The examined species all reached remarkable production that is the multiple of values presented in literature regarding herbaceous vegetation (e.g. grasslands) in the Carpathian Basin. Despite the species represented different functional groups and characterised by different stem count and biomass they all showed very similar dynamics. This can be explained by the above-average precipitation of the examination year and by the high level of $\mathrm{CO}_{2}$ fixation maintained for months. This latter feature can prove as one key feature leading to the success of this plant group. 
By examining the stand level $\mathrm{CO}_{2}$ fluxes of the five involved weed species regarding the entire vegetation period it can be concluded that values of two species endemic in Central Europe (Chenopodium album and Arthemisia vulgaris) are nearly identical while exceeding the average values of non-endemic $\mathrm{C}_{4}$ weed species (Amaranthus retroflexus, Sorghum halepense). The latter two plants, despite their different morphological features, can be characterised by almost the same average regarding $\mathrm{CO}_{2}$ uptake. The average $\mathrm{CO}_{2}$ fixation of the neophyte ragweed significantly exceeded that of all other plants involved. As for $\mathrm{C}_{3}$ weeds endemic species initiated more intensive $\mathrm{CO}_{2}$ uptake compared to the also $\mathrm{C}_{3}$ but invasive Ambrosia arthemisiifolia. $\mathrm{C}_{4}$ taxa reached higher NEE values later, similar to Ambrosia.

Further study is needed to define and measure the effects of intraspecific and interspecific competitions.

Acknowledgements. The publication was supported by Research Centre of Excellence project (14764/2016) of Faculty of Agricultural \& Environmental Sciences of Szent István University.

\section{REFERENCES}

[1] Ackerly, D.D., Coleman, J.S., Morse, S.R., Bazzaz, F.A. (1992): CO2 and Temperature Effects on Leaf Area Production in Two Annual Plant Species. - Ecology 73: 1260-1269.

[2] Barcza, Z., Bondeau, A., Churkina, G., et al. (2011): Modeling of biosphere-atmosphere exchange of greenhouse gases - Model based biospheric greenhouse gas balance of Hungary. - In: Haszpra, L. (ed.) Atmospheric Greenhouse Gases: The Hungarian Perspective. Pp. 295-330. Springer Publ., Doldrecht, Heidelberg, London, New York.

[3] Barney, J.N., Hay, A.G., Weston, L.A. (2005): Isolation and characterization of allelopathic volatiles from mugwort (Artemisia vulgaris). - Journal of Chemical Ecology 31: 247-265.

[4] Bazzaz, F A., Garbutt, K., Reekie, E.G., Williams W.E. (1989): Using growth analysis to interpret competition between a $\mathrm{C} 3$ and a $\mathrm{C} 4$ annual under ambient and elevated $\mathrm{CO}_{2}$.Oecologia Springer Berlin, Heidelberg 79: 223-235.

[5] Bernacchi, C.J., Coleman, J.S., Bazzaz, F.A., McConnaughay, K.D.M. (2000): Biomass allocation in old-field annual species grown in elevated $\mathrm{CO} 2$ environments: no evidence for optimal partitioning. - Global Change Biology 6: 855-863.

[6] Borjigidai, A., Hikosaka, K., Hirose, T. (2008): Carbon balance in a monospecific stand of an annual herb Chenopodium album at an elevated $\mathrm{CO} 2$ concentration. - Plant Ecology 203: 33-44.

[7] Brodersen, C., Lavergne, S., Molofsky, J. (2008): Genetic variation in photosynthetic characteristics among invasive and native populations of reed canarygrass (Phalaris arundinacea). - Biological Invasions 10:1317-1325.

[8] Čekić, S., Kovačević, Z. (2015): Ecological and Phytogeographical Characteristics of the Weed Flora in the Lijevče Plain. - Agro-knowledge Journal 16: 353-366.

[9] Coumou, D., Rhamstorf, S. (2012): A decade of weather extremes. - Nature Climate Change 2: 491-496.

[10] Czóbel Sz. (2007): Hazai gyepállományok szünfiziológiai és szünbotanikai állapota, különös tekintettel a földhasználati módok hatásaira. - Doktori disszertáció. SZIE, Gödöllö 169 p.

[11] Czóbel, Sz., Szirmai, O., Nagy, J., Balogh, J., Ürmös, Zs., Péli, E.R., Tuba, Z. (2008): Effects of irrigation on the community composition, and carbon uptake in Pannonian loess grassland monoliths. -Community Ecology 9:91-96. 
[12] Dippery, J.K., Tissue, D.T, Thomas, R.B. , Strain, B.R. (1995): Effects of low and elevated CO2 on $\mathrm{C} 3$ and $\mathrm{C} 4$ annuals. - Oecologia 101: 13-20.

[13] Dong, Y,S., Zhang, Qi, Y., Geng, Y. (2000): Fluxes of CO2, N2O and CH4 from a typical temperate grassland in Inner Mongolia and its daily variation, - Chines Science Bulletin 45: 1590-1594.

[14] Frank, A.B, Liebig, M.A, Hanson, J.D. (2002): Soil carbon dioxide fluxes in northern semiarid grasslands - Soil Biology and Biochemistry 34( 9): 1235-1241.

[15] Garbutt, K., Williams, W.E., Bazzaz, F.A. (1990): Analysis of the Differential Response of Five Annuals to Elevated CO2 during Growth. - Ecological Society of America Ecology 71:1185-1194.

[16] Gramig, G.G, Stoltenberg, D.E., Norman, J. M. (2006): Weed species radiation-use efficiency as affected by competitive environment. - Weed Science 54: 1013-1024.

[17] Hefting, M.M., Bobbink, R., de Caluwe, H. (2003): Nitrous Oxide Emission and Denitrification in Chronically Nitrate-Loaded Riparian Buffer Zones. - Journal of Environmental Quality 32: 1194-1203.

[18] Holzner, W., Numata, M. (2013): Biology and ecology of weeds. - Springer Science \& Business Media, pp. 461.

[19] Horváth, L., Führer, E., Lajtha, K. (2006): Nitric oxide and nitrous oxide emission from Hungarian forest soils; linked with atmospheric N-deposition. - Atmospheric Environment 40:7786-7795.

[20] Hunt, J. E., Kelliher, F.M., McSeveny, T.M., Byers, J.N. (2002): Evaporation and carbon dioxide exchange between the atmosphere and a tussock grassland during a summer drought. - Agricultural and Forest Meteorology 111(1): 65-82.

[21] Li, C., Frolking, S., Butterbach-Bahl., K. (2005): Carbon Sequestration in Arable Soils is Likely to Increase Nitrous Oxide Emissions, Offsetting Reductions in Climate Radiative Forcing - Climatic Change 72(3): 321-338.

[22] MacDonald, J. A., Fowler, D., Hargreaves, K.J., Skiba, U., Leith, I.D.,. Murray M.B. (1998): Methane emission rates from a northern wetland; response to temperature, water table and transport. - Atmospheric Environment 32: 3219-3227.

[23] Nielsen, E.T., Karpa, D., Mooney, H.A., Field, C. (1993): Patterns of stem assimilation in two species of invasive legumes in costal California - Am. J. Bot. 80: 1126-1136.

[24] Papen, H., Daum, M., Steinkamp, R., Butterbach-Bahl, K. (2001): $\mathrm{N}_{2} \mathrm{O}$ and $\mathrm{CH}_{4}$-fluxes from soils of a N-limited and $\mathrm{N}$-fertilized spruce forest ecosystem of the temperate zone. - J. Appl. Bot. 75:159-163.

[25] Pintér, K., Barcza, Z., Balogh, J., Czóbel, Sz., Csintelan, Zs., Tuba, Z., Nagy, Z. (2008): Interannual variability of grasslands' carbon balance depends on soil type. - Community Ecology 9( Supplement):43-48.

[26] Soussana, J.F., Allard, V., Pilegaard, K. et al. (2007): Full accounting of the greenhouse gas $\left(\mathrm{CO}_{2}, \mathrm{~N}_{2} \mathrm{O}, \mathrm{CH}_{4}\right)$ budget of nine European grassland sites. - Agr. Ecosyst. Environ. 121: 121-134.

[27] Suyker, A. E., Verma, S. B., Burda, G. G. (2003): Interannual variability in net $\mathrm{CO}_{2}$ exchange of a native tallgrass prairie. - Global Change Biology 9(2): 255-265.

[28] Szirmai, O., Horel, J., Neményi, A., et al. (2014): Overview of the collections of the first agrobotanical garden of Hungary. - Hungarian Agricultural Research 23: 19-25.

[29] Yamuki, S., Harrison, R.M., Goulding, K.W.T., Webster, C.P. (1997): $\mathrm{N}_{2} \mathrm{O}$, $\mathrm{NO}$ and $\mathrm{NO}_{2}$ fluxes from a grassland: Effect of soil pH. - Soil Biology and Biochemistry 29: 11991208.

[30] Yuste, J.C., Janssens, I.A., Carrara, A., et al. (2004): Annual Q(10) of soil respiration reflects plant phenological patterns as well as temperature sensitivity. - Glob. Change Biol. 10: 161-169.

[31] Valentini, R., Gamon, J. A., Field, C. B. (1995): Ecosystem Gas Exchange in a California Grassland: Seasonal Patterns and Implications for Scaling - Ecological Society of America 76( 6): 1940-1952. 
[32] van Kleunen, M., Dawson, W., Essl, F., et al. (2015): Global exchange and accumulation of non-native plants. - Nature 525: 111-103.

[33] Ward, J.K., Tissue, D.T., Thomas, R.B., Strain, B.D.R. (1999): Comparative responses of model $\mathrm{C} 3$ and $\mathrm{C} 4$ plants to drought in low and elevated CO2. - Global Change Biology 5: $857-867$. 